\title{
Should the U.S. Shut Down Gitmo?
}

This panel discussion, held on 27 June 2006 and sponsored by the Council on American-Islamic Relations (CAIR), featured James Yee, a 1990 West Point graduate and Muslim chaplain assigned to Camp Delta (Guantanamo 
Bay) and attorney Gene Fidell of Feldesman, Tucker, Leifer, and Fidell, who has worked on cases involving Guantanamo Bay inmates. The discussion took place at the Rayburn House Office Building in Washington, DC.

After making opening remarks on illegal immigrants and terrorism, Mohammad Nimer (research director, CAIR) introduced Chaplain Yee, who had served at Camp Delta from November 2002 to September 2003. While there, he experienced the detention center's living conditions and received awards and recognition for his service. On 10 September 2003, however, he was arrested and accused of espionage, aiding the enemy, mutiny, and sedition. Eventually, he was locked up alongside enemy combatants Yasser Hamdy and Jose Padilla in a naval brig in South Carolina. Later, all charges were dropped, including unrelated charges regarding national security.

Yee explained his role as advocating for the free exercise of worship. He advised the camp commander on religious aspects of prison operations and listened to prisoners' complaints and concerns, including authorized and unescorted access to the cells. In addition, he observed detainee treatment and made recommendations. He described two operations: detention operations run by military police or guards (e.g., providing them with clothes) and intelligence gathering, which included extracting information. Yee was assigned to the former group, as the commanding general at the time, Major General Geoffrey Miller, considered it unethical for the chaplain to be present during intelligence gathering operations.

Yee mentioned the suicides of 10 June 2006, which sparked the debate of whether the United States can still be considered the world leader in human rights. Talking about prisoner abuse, he presented "Gitmo's secret weapon": the use of religion against the detainees. For example, prisoners told him that they were forced to sit on a satanic circle (painted on the floor) while shackled at the wrists, ankles, and waist (the military's "three-piece suit"). Forced into the prayer position, the guards would then declare Satan, to be their God. Female interrogators would touch male prisoners inappropriately (e.g., their genitals) and force the prisoners to touch them. Also, the Qur'an was ripped, thrown, kicked, and stepped on, which ignited prisoner protests. All of this abuse led to mass suicide attempts. In January 2003, a Saudi prisoner who attempted suicide slipped into a coma for months and later recovered with brain damage before he was returned home.

When asked how to help prevent prisoner deaths, Yee recommended a policy of handling the Qur'an with respect. Culture was also abused, as prisoners sometimes were forced to wear the Israeli flag. But Islam was the cornerstone of abuse used to destroy the detainees psychologically. Today, the hunger strikes, protests, and suicide attempts revolve around their indefinite 
detention, uncertainty, and lack of due process. The military's view of suicides as an "act of asymmetrical warfare," as well as a State Department official's statement that they were a "good public relations move designed to attract attention," are, according to Yee, offensive and unproductive.

Attorney Eugene Fidell, who handled Chaplain Yee's case, discussed the detainees' "combatant status," which makes it hard for them to defend themselves. He added that their status as "intelligence sources" is slim to none, as only a few have been charged. Fidell explained that a military commission can be held anywhere, as Guantanamo is inconvenient, and that the key reason for confining them at Guantanamo was to put them beyond the federal courts' reach. The Supreme Court rejected this argument in 2004.

During the question and answer period, Yee stated that religious and sexual humiliation was a deliberate and systematic policy, for he felt that there was strong anti-Muslim sentiment toward prisoners and observant American Muslim personnel. Asked about the Geneva Conventions and the issue of cruel and inhumane treatment, Fidell agreed that such treatment violates the convention. Yee added that using religion against the detainees is against this country's character and the freedom of religion. He felt that such actions allows terrorists and those who harbor anti-American sentiments to point out that the "war on terror" is a "war against Islam" and that this hinders intelligence gathering.

When asked if any of the intelligence gathered at Guantanamo had prevented future terrorist attacks, Yee replied that such information was deemed "classified." In response to another question, he replied that a United States Southern Command website mentions the abuse of the Qur' an under media releases, along with Lieutenant General Schmidt, who authored the Schmidt report. According to Yee, no senior leadership has been held accountable for any of the abuses at Guantanamo Bay, although Geoffrey Miller, a four-star general, was reprimanded.

Surprisingly, this camp continues to exist despite two Supreme Court rulings (2004 and 2006) that its inmates are entitled to the prisoner of war protections under the Geneva Conventions and that it is subject to American law. To date, no prisoners have had a hearing. Holding prisoners without due process, and then abusing and humiliating them, is unjust and unethical and violates their basic human rights. This is even truer when, according to the Bush administration's own admission, these detainees seem to have had nothing to do with terrorism. 